\title{
Prospects of Custard Apple Value Chain Development in Rajasthan
}

\author{
Shailza $^{1 *}$, Latika Sharma ${ }^{1}$, S.S. Burark ${ }^{1}$, R.A. Kaushik ${ }^{2}$ and G.L. Meena ${ }^{1}$ \\ ${ }^{1}$ Department of Agricultural Economics \& Management, MPUAT, Udaipur, Rajasthan, India \\ ${ }^{2}$ Department of Horticulture, MPUAT, Udaipur, Rajasthan, India \\ *Corresponding author: shell310569@gmail.com (ORCID ID: 0000-0003-1672-2254)
}

Received: $17-12-2019$

Revised: $14-04-2020$

Accepted: 28-05-2020

\begin{abstract}
Custard apple is one of the wildly found perishable crop of forest areas. Rajasthan is one of the top ten custard apple growing states in our country. In Rajasthan, custard apple is mainly found in southern districts of Rajasthan. The present study was carried out to analyze prospects of value chain development in custard apple marketing in Rajasthan. The secondary data has been obtained and analyzed from Directorate of Horticulture, Government of Rajasthan for the year, 2017-18. The perishable nature of custard apple makes difficult to transport it to distant places thereby tribals are forced to sell the fruit at throwaway prices i.e. approx. $₹ 10 / \mathrm{Kg}$ on roadsides. It was observed that interventions involving improved cultivation practices and reduction in post harvest losses would increase the production level by 50 per cent and 20 per cent, respectively, whereas value addition activities through processing would give better returns to the processors as well as to the tribal harvesters The study further highlighted compound annual growth rate of custard apple area and production along with the need of investments in research \& development to ensure improved cultural practice to establish custard apple orchards to increase yield per hectare, introduction of improved varieties, processing technology and overhauling of the value chain.
\end{abstract}

\section{Highlights}

(0) Value chain development help in increasing the shelf-life of perishable fruits.

( U Upliftment of the socio- economic status of tribal households dependent on custard apple collection from forest areas.

Keywords: Custard apple, value chain, interventions, socio-economic status.

Custard apple, Annona squamosa (Sweetsop, Sitaphal, Sharifa, Ates), is most widely grown species of Annonaceae family, originated and introduced in India from Tropical America. In India, total area* under custard apple was 44 thousand hectare which led to production* of 367 thousand MT whereas Rajasthan had an area* of 241.65 hectares $(0.54$ per cent) and production* of 1481.49 MT (0.40 per cent) under custard apple during 2017-18, which

\footnotetext{
* The actual area and production under custard apple may vary, as custard apple is wildly grown horticultural crop of forest areas, therefore, it is very difficult to quantity the actual area and production of it.
}

signified that Rajasthan holds an important role in area and production of custard apple (Annual Report, Directorate of Horticulture, Government of Rajasthan, 2018).

It is of great importance for tribals of the state as it widely grows in tribal belts of Rajasthan which includes areas of Udaipur, Chittorgarh, Jhalawar, Dungarpur, Bhilwara and Rajsamand districts.

How to cite this article: Shailza, Sharma, L., Burark, S.S., Kaushik, R.A. and Meena, G.L. (2020). Prospects of custard apple value chain development in Rajasthan. Economic Affairs, 65(2): 207-212.

Source of Support: None; Conflict of Interest: None (c) $\rightarrow$ 
During 2017-18, Udaipur district was having highest area of 109 hectares with the production of 525 MT of custard apple. Chittorgarh district was leading in terms of production of custard apple during 2017-18 with total area of 79 hectare and 746 MT of production of custard apple (Annual Report, Directorate of Horticulture, Government of Rajasthan, 2018). It meets the economic needs of tribal population who are dependent on its marketing. Due to perishable nature of custard apple tribals collect the custard apple and sell them on roadsides at very low price i.e., less than ₹ 10 per Kg (Final report, National Agriculture Innovation Project, 2013). During 2018-19, custard apple sold in the market at varying prices depending upon the time of sale. In the morning hours of the custard apple season the fruit was sold at ₹ 60 per $\mathrm{Kg}$ whereas in the same evening prices reduced to ₹ 20 per $\mathrm{Kg}$. This huge variation in prices depicts the highly perishable nature of fruit. Therefore, there is a need to make tribal people who are collecting custard apple from forest area acquainted with processing and marketing practices which further would lead to higher output, employment and profit for years (Tripathi, 2016). There is very little investment in custard apple processing, despite the fact it will give them better economic returns. This fruit can be processed into various value added products such as ice creams, faluda, squashes, shrikhand, basundi, shakes. Investment in processing into value added pulp and various other products will greatly reduce the waste experienced especially during the season of glut (Reddy et al. 2010).

\section{METHODOLOGY}

Rajasthan is one of the leading producers of custard apple in the country. The present study focuses on compound annual growth rate in area and production of custard apple along with SWOT analysis of custard apple value chain, the model value chain of custard apple and efforts towards its development and challenges and strategies for harnessing the potentials of custard apple for the development of tribal community of Southern Rajasthan.

Sampling Procedure: For calculation of price spread in custard apple marketing by tribals, Udaipur city of Rajasthan was purposively selected as the city was serving as largest market of custard apple. For calculation of price spread a sample of 25 tribals was purposively selected who were directly selling custard apple in Udaipur city area.

Analytical Tools: For analyzing the compound annual growth rate of area and production the exponential function was used.

$$
Y=a b^{t} e^{U t}
$$

Where, $Y=$ Area/ Production of custard apple

$a=$ intercept,$b=$ regression coefficient, $U_{t}=$ stochastic coefficient in year $\mathrm{t}$

Log linear form of equation (1) is:

$$
\log Y=\log a+t \log b+U_{t}
$$

Ordinary Least Square (OLS) technique was used to estimate equation (2)

Compound annual growth rate was calculated as:

$$
g=(b-1) 100
$$

where, $b=$ antilog of $\log b$

$g=$ compound annual growth rate (in per cent per annum)

Price Spread: Various measures of price spread would be calculated as follows:

Share of tribal in consumer rupee $=$ Price received by tribals excluding marketing cost/ price paid by consumer

Value added $=$ Price paid by consumer - total cost of marketing

\section{RESULTS AND DISCUSSION}

Rajasthan is one of the leading producers of custard apple in the country. The compound annual growth rate indices for area and production of custard apple in Rajasthan and India can be depicted from Table 1.

Table 1: Compound annual growth rate of custard apple (CAGR in per cent per annum)

\begin{tabular}{lllll}
\hline & \multicolumn{3}{c}{ Rajasthan } & \multicolumn{2}{c}{ India } \\
\hline Year & $\begin{array}{l}\text { Area (th. } \\
\text { Ha) }\end{array}$ & $\begin{array}{l}\text { Production } \\
\text { (th. MT) }\end{array}$ & $\begin{array}{l}\text { Area (th. } \\
\text { Ha) }\end{array}$ & $\begin{array}{l}\text { Production } \\
\text { (th. MT) }\end{array}$ \\
\hline $2011-12$ & 0.90 & 6.80 & 18.50 & 127.30 \\
$2012-13$ & 0.87 & 7.11 & 19.55 & 135.64 \\
$2013-14$ & 0.58 & 5.65 & 21.77 & 165.15 \\
$2014-15$ & 0.53 & 4.56 & 29.87 & 228.37
\end{tabular}




\begin{tabular}{lllll}
$2015-16$ & 0.52 & 6.12 & 36.83 & 289.01 \\
$2016-17$ & 0.54 & 4.28 & 44.00 & 383.00 \\
$2017-18$ & 0.24 & 1.48 & 46.00 & 401.00 \\
$2018-19$ & 0.21 & 1.40 & 40.00 & 338.00 \\
CAGR & $-18.19^{* *}$ & $-20.66^{* *}$ & $15.35^{* *}$ & $19.57^{* *}$ \\
\hline
\end{tabular}

Source: Indiastat.com, Directorate of Horticulture, Rajasthan. ** significant at 5 per cent level of significance.

The area and production of custard apple in Rajasthan witnessed negative growth rate of -18.19 per cent and -20.66 per cent per annum, respectively, which signified that there must be shift in cultivation of crops towards some other crop. On the other hand the area and production of custard apple in the country witnessed positive growth rate of 15.35 per cent and 19.57 per cent, respectively. it can be concluded that in the country as a whole custard apple showed increase in level of area and production whereas in Rajasthan, there existed fall in area and production of custard apple. The decrease in area and production led to increase in demand for value added products due to shortage of fruit in the market so that the product can be stored for longer time (Kallega et al. 2015).

Marketing of custard apple: Tribals market the fruit at nearby cities or road sides. The perishable nature of custard apple makes it difficult to transport it to distant places. The amount received was also lower due to small shelf life. The price spread in marketing of custard apple to nearby cities/ roadsides is shown in table 2.

Table 2: Price Spread in marketing of custard apple

\begin{tabular}{lll}
\hline Particulars & $\begin{array}{l}\text { Amount } \\
\text { (₹ per quintal) }\end{array}$ & Percentage \\
\hline Amount received by tribals & 1835.00 & 83.40 \\
Collection charges & 135.00 & 6.13 \\
Transportation & 85.00 & 3.86 \\
$\begin{array}{l}\text { Packing Material/ Basket } \\
\text { charges }\end{array}$ & 110.00 & 5.00 \\
Losses & 35.00 & 1.60 \\
Total cost in marketing & 365.00 & 16.59 \\
Amount Paid by consumer & 2200.00 & \\
\hline
\end{tabular}

Source: Author's Calculation.

It can be depicted from Table 2 that the tribals were having 83.40 per cent share in consumer's price paid whereas 16.59 per cent was incurred as marketing cost. Although the share received was high due to non interference of middlemen but the amount received was less which signified opportunity for value chain development. Similar results were observed in the findings of Mishra et al. (2014).

Value Chain Development: The major issues which the tribals face are: (a) lack of rejuvenation technology, (b) harvest and post harvest losses, (c) lack of processing technologies and value addition and (d) unorganized market. To overcome various challenges in marketing of custard apple, development of value chain is of utmost importance. It helps to increase the shelf life of the fruit. Value chain describes the analysis of all the activities which are essential to bring a product or service from point of conception, through the different phases of production/ marketing (involving a combination of physical transformation and value addition through processing, etc.) and then followed by final disposal after use (Final report, National Agriculture Innovation Project, 2013). The various steps involved in custard apple value chain are shown in Fig. 1.

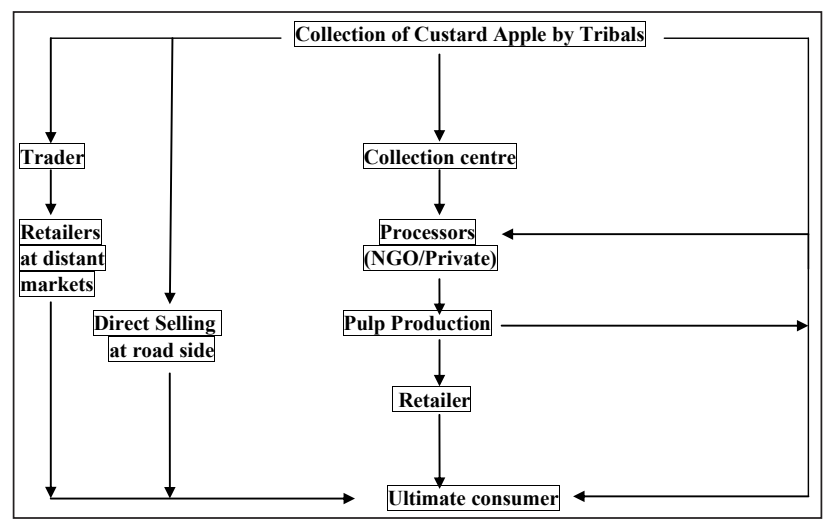

Fig. 1: Value chain for Custard Apple

SWOT Analysis: The first step in development of short and long term strategic planning is to analyze various internal and external factors affecting the performance of value chain of custard apple which is done by SWOT analysis. SWOT analysis of custard apple value chain to evaluate strength, weaknesses, opportunities and threats in the process is shown in Table 3.

There are various threats and weaknesses as enlisted mentioned in the above table which are hampering the development of value chain of this precious fruit. Custard apple is the gift of nature to the tribals as it grows wildly without much investment and climatic conditions of the Southern Rajasthan also make it favourable to grow over there. 
Table 3: SWOT Analysis of Custard Apple Value Chain

\begin{tabular}{|c|c|}
\hline \multirow[t]{4}{*}{ Strengths } & Low cost of production \\
\hline & Low labour cost \\
\hline & Suitable climate of Southern Rajasthan \\
\hline & Growing market of the product \\
\hline \multirow[t]{12}{*}{ Weaknesses } & $\begin{array}{l}\text { Custard apple production naturally } \\
\text { found in limited area }\end{array}$ \\
\hline & Tribals do not undertake its cultivation \\
\hline & Lack of market information \\
\hline & Lack of expertise \\
\hline & High pre \& post harvest losses \\
\hline & Lack of infrastructure/ storage units \\
\hline & Lack of capital \\
\hline & Unorganized market channels \\
\hline & High transportation cost \\
\hline & Low R \& D capability \\
\hline & Lack of vision and policy \\
\hline & Lack of interaction with stakeholders \\
\hline \multirow[t]{9}{*}{ Opportunities } & Reduction in post harvest losses \\
\hline & Improvement in quality of product \\
\hline & High processing opportunities \\
\hline & High product value \\
\hline & High by- product value \\
\hline & Longer shelf life \\
\hline & Well organized structure for storage \\
\hline & Better returns \\
\hline & $\begin{array}{l}\text { Employment Generation in processing } \\
\text { units. }\end{array}$ \\
\hline \multirow[t]{5}{*}{ Threats } & Climate change \\
\hline & $\begin{array}{l}\text { Non availability of funds for setting up } \\
\text { processing units in the area }\end{array}$ \\
\hline & Potentially high $\mathrm{R} \& \mathrm{D}$ expenses \\
\hline & Inconsistent Government policies \\
\hline & Lack of competitiveness in the market. \\
\hline
\end{tabular}

Therefore, there is need to focus upon the strengths and opportunities provided by value chain to uplift the socio- economic status of the tribals of the area. Particularly, interventions and policies must be introduced in such areas where the custard apple cultivation is undertaken or the tribals are mainly dependent on its collection from forest areas for their livelihood.

Impact of interventions on Value Chain of Custard Apple: In order to ensure that the tribals receive better prices for their produce the intervention involving value addition to the fruit before selling it in the market is required. The strategy of value addition on agricultural produce provides ample opportunity for revenue generation, employment generation and effective post harvest management. The processing of raw fruit into various innovative products like pulp, powder, etc. promotes market acceptability and gives the products high economic value (Kaushik, 2013). Experts from MPUAT, Udaipur provided technical support for this intervention. It started with training the tribals about right stage of harvesting i.e when the fruit slightly turned yellowish in colour followed standardized rejuvenating technology, pulp extraction equipment developed and browning free technology was adopted for the processing of custard apple, which helped in increasing the shelf life of finished product from a few days to more than a year. It involved the establishment of collection centre at village level, processing unit, a storage unit and marketing network to promote sale of the produce. Tribals were provided training on the maturity indices and processes like grading, sorting, weighing, processing, etc. (Kaushik, 2013). The impact of interventions are shown in Fig. 2 which are based on the production of custard apple from 4000 hectare of project area (including custard apple grown in forest area) under NAIP in Rajasthan.

Value Addition at State level: Value chain basically consist of series of value adding activities which led to the improvement in quality of product being marketed and also results in better returns to the functionaries involved at each level (Kaplinsky and Morris, 2001). In India, total area under custard apple was 44 thousand hectare which led to production of 367 thousand MT whereas Rajasthan had an area of 241.65 hectares $(0.54$ per cent) and production of 1481.49 MT (0.40 per cent) under custard apple during 2017-18 (Annual Report, Directorate of Horticulture, Government of Rajasthan, 2018). Table 4 shows value addition and increase in the income level by implying the outcomes of intervention as indicated in figure 2 to the state level production during the year 2017-18. From the calculations in table 4, it can be concluded that after all the possible interventions value of custard apple would increase by ₹ 115.21 Lakhs from ₹ 74.07 Lakhs. If the improved practices at production level, management of post harvest losses and $10 \%$ of the total production is processed (as 


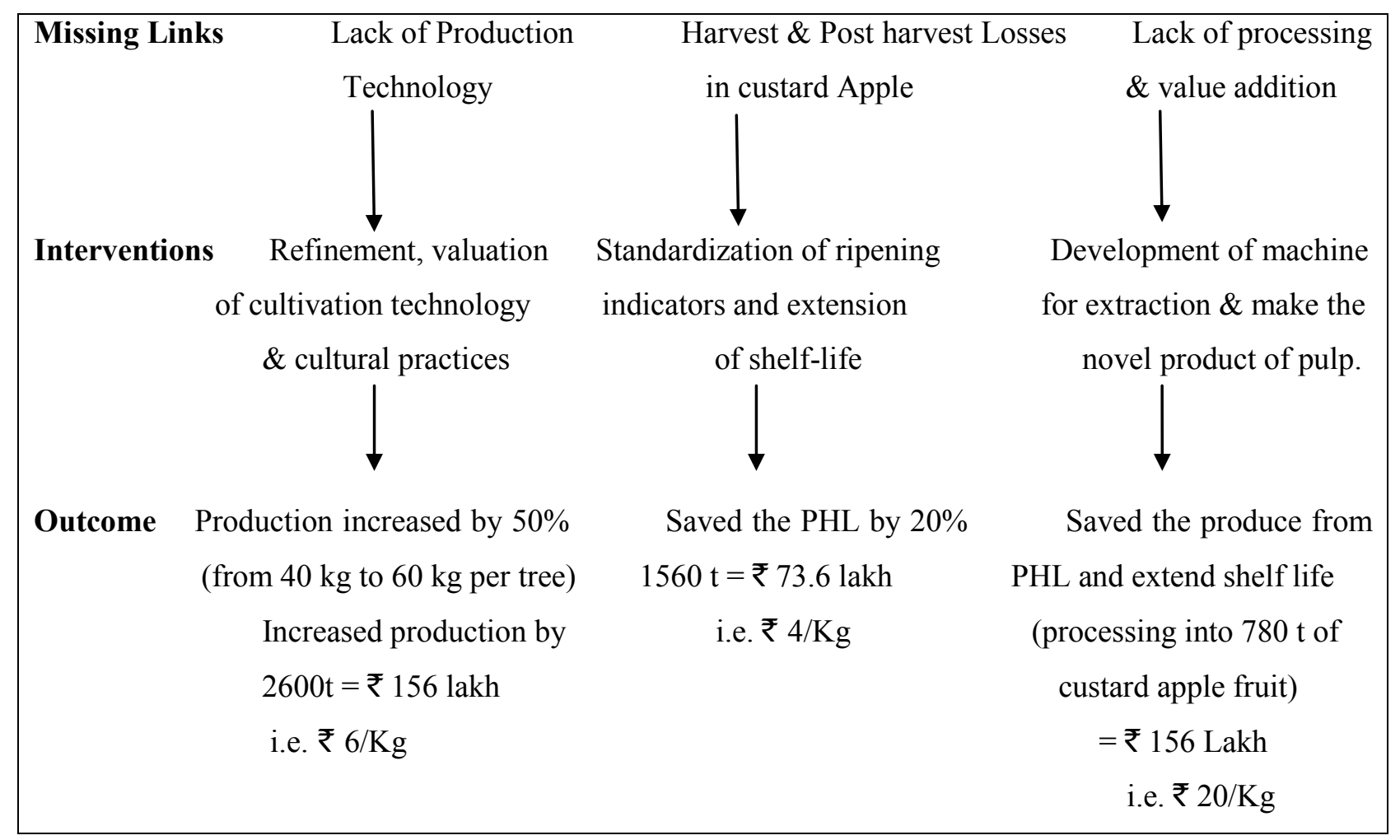

Source: Technology on custard apple processing and value chain: A step towards doubling the income of tribals (Kaushik, 2013)

Fig. 2: Impact of interventions on the value chain of custard apple

Table 4: Economics of Value Chain of Custard Apple

\begin{tabular}{ll}
\hline Parameter & Amount \\
\hline Total Area under custard apple in the state (during 2017-18) & 241.65 ha \\
Total Production (during 2017-18) & MT \\
Value of 1481.49 MT custard apple (@ ₹ 5/Kg)* & ₹ 74.07 Lakhs \\
If interventions implied as suggested by MPUAT experts (Under NAIP) & \\
Increase in Production by improved practices (50\% of production hike) & $740.74 \mathrm{MT}$ \\
Hike of Production in Value terms (@ ₹ 6/Kg) & $₹ 44.44$ Lakhs \\
Total production after opting improved practices & $2222.23 \mathrm{MT}$ \\
Saving in Post Harvest Losses (20\%) & $444.44 \mathrm{MT}$ \\
Post harvest losses reduced in Value terms (@ ₹ 4/Kg)* & ₹ $17.77 \mathrm{Lakhs}$ \\
Overall Production level after interventions & $2666.67 \mathrm{MT}$ \\
Value of 2666.67 MT custard apple (a+b+c) & $₹ 136.28$ Lakhs \\
Value Added by Processing (If 10\% of production is being processed into pulp i.e. 266.66 MT, @ ₹ 20/Kg) & ₹ 53 Lakhs \\
Total Returns (a+b+c+d) & ₹ 272.56 Lakhs \\
Possible Value Addition by all interventions (b+c+d) & ₹ 115.21 Lakhs \\
\hline
\end{tabular}

*Calculations done on the basis of Fig. 2 (Kaushik, 2013 and Kaplinsky and Morris, 2001).

given in Fig. 2) then the value of total returns from custard apple to state during 2017-18 would be ₹ 272.56 Lakhs which included ₹ 53 Lakhs of value addition by processing.

Strategies towards harnessing the potentials of custard apple in Rajasthan: Rajasthan state of India is blessed with natural biodiversity of the crop with more than 50 per cent of state's forest area situated under Aravalli Hills. The wild land races of custard apple are found distributed all along as a natural stand over an acreage of approximately 673 hectares in the Aravalli range of forest scattered 
across Udaipur, Rajsamand, Chittorgarh, Kota, Baran and Jhalawar districts (Bhatnagar, 2016). Custard apple is one of the species of Annonaceae family which wildly found in the forest areas. It is generally found growing spontaneously in wild forests, scrub jungles, rocky slopes as a semi-wild fruit in Southern Rajasthan. Out of total near about $30 \%$ of the produce go waste in transportation or post harvest losses. Therefore, if the state is to take advantage of the huge potentials of this underutilized fruit, the following strategies have to be implemented:

(a) Control over the post harvest losses,

(b) Training should be given on harvesting indicators and post harvest handling of fruit,

(c) Adequate funding for research and development,

(d) Establishment of processing units and collection centers and

(e) Establishment of custard apple orchards with high yielding varieties.

\section{CONCLUSION}

There is a vast scope for the development of tribals who are dependent on custard apple collection from the forest areas (Tripathi, 2016). But the need is to acquaint them about the various losses and strategies to mitigate them. The technology developed by the experts of MPUAT is a crucial and advantageous step towards development of value chain of this underutilized fruit. Investments in processing units will have a great multiplier effect as it will not only improve the state's economy, but will also ensure creation of employment and enhance the income and living standards of all the actors in the value chain. At the root of the problem is research and development. All levels of the value chain require investments in the research and development to ensure improved cultural practices to establish custard apple orchards to increase yield per hectare, introduce improved varieties, processing technology and overhauling of the value chain.

\section{REFERENCES}

Annual report of Directorate of Horticulture. 2018. Government of Rajasthan.

Bhatnagar, P., Singh, P.C., Jain, P.C. and Meena, C.B. 2016. Prospects and potential of custard apple in Rajasthan. Hort. Flora Research Spectrum, 5(4): 331-334.

Final Report. National Agricultural Innovation Project (Indian Council of Agricultural Research) 2013. A Value chain on commercial Exploitation of Underutilized Fruits of Tribal Zones of Rajasthan.

Kallega, H.K., Kar, A. and Mathur, V.C. 2015. Temporal and spatial performance of horticultural crops in India. Economic Affairs, 60(3): 367- 373.

Kaplinsky, R. and Morris, M. 2001. A Handbook for Value Chain Research. International Development Research Centre, 1(1): 4-6.

Kaushik, R.A. 2013. Technology on custard apple processing and value chain: A step towards doubling the income of tribals. Manual of RCA Alumni Association, Udaipur, 1(3): 72-75.

Mishra, S., Singh, R. and Singh, O.P. 2014. Economic analysis of marketing of major vegetables in Varanasi district of Uttar Pradesh, India. Economic Affairs, 59(4): 649-652.

Post Harvest Management of Custard Apple Enhanced livelihood of Tribals in Udaipur. Web Page. Indian Council of Agricultural Research. https://icar.org.in/node/357

Reddy, G.P., Murthy, M.R.K. and Meena, P.C. 2010. Value chains and retailing of fresh vegetables and fruits, Andhra Pradesh. Agricultural Economics Research Review, 23(conf issue): 455-460.

Tripathi, S. 2016. Livelihood dependency of Garasia tribes utilizing non timber forest products in Abu Road area of Sirohi district in Rajasthan, India. International Journal of Advanced Research, 4(7): 498-504. 